\title{
Renaisans Eropa dan Transmisi Keilmuan Islam ke Eropa
}

\author{
Hasyim Asy'ari \\ Dosen Pendidikan Bahasa Arab, Fakultas Tarbiyah \\ Institut Pesantren KH. Abdul Chalim, Bendunganjati Pacet Mojokerto, Jawa Timur \\ hasyim.ikhac@gmail.com
}

\begin{abstract}
Renaissance are so important and considered historians as the starting point for the development of European civilization. First, European people succeed many achievement in various sector, namely: art, philosophy, literature, science, politics, education, religion, trade and others. Second, Renaissanse has revived the ideals, the realm of thought, the philosophy of life which then structures the standards of the modern world such as optimism, hedonism, naturalism and individualism. Third, the Ancient Greeks and Rome legacies need to revived. Fourth, the incorporation of secular humanism that shifts the human thinking orientation from the theocentric to the anthropocentric. Science had the transmission, dissemination, and proliferation to the Western world that supports the epoch of the Renaissance in Europe. Through the Islamic World, the Western world gained access to deepen and modernized science.
\end{abstract}

Keywords: Renaissance, scientific transmission, Islam in Europe.

\begin{abstract}
Abstrak
Zaman Renaisans begitu penting dan dianggap para sejarawan sebagai starting point perkembangan peradaban Eropa. Pertama, karena pada masa ini manusia berhasil mencapai prestasi gemilang dalam berbagai bidang seni, filsafat, literatur, sains, politik, pendidikan, agama, perdagangan dan lain-lain. Kedua, Renaisans telah membangkitkan kembali cita-cita, alam pemikiran, filsafat hidup yang kemudian menstrukturisasi standar dunia modern seperti optimisme, hedonisme, naturalisme dan individualisme. Ketiga, terjadinya kebangkitan kembali minat mendalam terhadap kekayaan warisan Yunani dan Romawi Kuno. Keempat, terjadinya kebangkitan humanisme sekuler yang menggeser orientasi berpikir manusia dari yang bersifat teosentrik menjadi antroposentris. Ilmu pengetahuan mengalami transmisi, diseminasi, dan proliferasi ke dunia Barat yang mendukung muculnya zaman Renaisans di Eropa. Melalui dunia Islam, dunia Barat mendapat akses untuk mendalami dan mengambangkan ilmu pengetahuan modern.
\end{abstract}

Kata kunci: Renaisans, transmisi keilmuan, Islam di Eropa.

\section{PENDAHULUAN}

Abad pertengahan menjadi masa keemasan bagi orang Islam. Ilmu pengetahuan berkembang dengan pesat. Perluaasan wilayahnya mencapai wilayah Eropa, salah satunya adalah Andalusia. Kejayaan Islam berlangsung cukup lama hingga sampai pada masa kehancurannya. Dengan kehancuran kejayaan Islam ini bersamaan dengan Renaisans di Eropa. 
Barat menyebut abad-abad pertengahan (antara abad ke-9 sampai abad ke14) sebagai ‘The Dark Ages' (abad-abad kegelapan). Hal ini benar dan tepat hanya untuk dunia Barat, sedangkan bagi Islam abad pertengahan adalah 'Ashr alIzdihar' (zaman kejayaan) dan 'Al-Ashr Adz-Dzahabi' (zaman keemasan). Di saat Barat diliputi oleh kegelapan-kegelapan, Islam ditimur telah bersinar terang dengan peradaban-peradaban kemanusiaan, bahkan Islam pun telah menerangi Eropa yang gelap dengan bijaksana.

Di saat Timur (Islam) menikmati cahaya peradaban yang begitu tinggi, ternyata di wilayah jajahan Romawi Kristen mengalami kegelapan dan kebodohan. Kilyam Dabur wali kota Thabariyah menceriterakan bahwa seorang jawara penunggang kuda yang sakit keras dibawa kepada seorang Uskup Agung untuk mendapatkan pengobatan. Tatkala Uskup melihat Pasien, dia meminta lilin, setelah lilin kami berikan, dia melemaskannya dan membentuknya seperti ruas jari, kemudian masing-masing diletakkan disamping hidungnya. Setelah itu sang jawara meninggal. Kami berkata kepadanya bahwa dia telah meninggal. Dia bilang "ya, dia tadi tersiksa maka saya sumbat lubang hidungnya sampai mati dan tenang beristirahat."

Selain itu, Eropa berkembang menjadi pesat juga mendapatkan sumbangsih dari orang-orang Islam. Diantaranya adalah transmisi keilmuan Islam ke Eropa. Transmisi ini berupa kontak langsung ataupun para sarjana Eropa belajar pada orang Islam yang saat itu mengalami masa kejayaan.

\section{PEMBAHASAN}

\section{A. Renaisans Eropa}

Zaman Renaisans (abad XIV-XVI) adalah satu abad keemasan (Golden Age) dalam sejarah peradaban barat. Zaman ini merupakan fase transisi yang menjebatani zaman kegelapan (Dark Ages) dengan zaman pencerahan (Enlightenment Age). Dengan lahirnya Renaisans, seberkas kemilau cahaya peradaban barat mulai bersinar. Tanpa Renaisans, Eropa mungkin tidak akan menapaki abad-abad modern dengan begitu cepat. ${ }^{1}$

Secara etimologis (bahasa Prancis) Renaisans, berasal dari kata Re, (kembali) dan Neitre (lahir) berarti 'kelahiran kembali.' Dalam konteks sejarat barat, istilah ini mengacu pada terjadinya kebangkitan kembali minat yang sangat besar dan mendalam terhadap kekeyaan warisan Yunani dan Romawi kuno dalam berbagai aspeknya. Manusia Renaisans begitu bersemangat mempelajari karya-karya pemikir agung Yunani Kuno seperti Plato, Plotinus dan Aristoteles. ${ }^{2}$

Sesudah mengalami masa kebudayaan tradisional yang sepenuhnya diwarnai oleh ajaran kristiani, kini orang mencari orientasi dan inspirasi baru sebagai alternative bagi kebudayaan tradisional tersebut, dan perhatian mereka

\footnotetext{
${ }^{1}$ Ahmad Suhelmi, Pemikiran Politik Barat ( Jakarta: Gramedia Pustaka Utama, 2007), h 109

2Ibid., h 110.
} 
diarahkan pada kebudayaan Yunani-Romawi sebagai satu-satunya kebudayaan lain yang mereka kenal dengan baik. Kebudayaan klasik ini dipuja dan dijadikan model serta dasar bagi peradaban manusia. ${ }^{3}$

Pertama, karena pada masa ini manusia berhasil mencapai prestasi gemilang dalam berbagai bidang seni, filsafat, literatur, sains, politik, pendidikan, agama, perdagangan dan lain-lain. Kedua, Renaisans telah membangkitkan kembali cita-cita, alam pemikiran, filsafat hidup yang kemudian menstrukturisasi standar-standar dunia modern seperti optimisme, hedonisme, naturalisme dan individualisme. ${ }^{4}$

Ketiga, terjadinya kebangkitan kembali minat mendalam terhadap kekayaan warisan Yunani dan Romawi Kuno. Keempat, terjadinya kebangkitan humanisme sekuler yang menggeser orientasi berfikir manusia dari yang bersifat teosentrik menjadi antroposentris. Kelima, terjadinya pemberontakan terhadap gereja yang kemudian muncul kebebasan intelektual dan agama. Dalam hal masa ini telah memaklumkan bahwa manusia sendiri adalah kaidah segala sesuatu yang ada, bukan Gereja atau Alkitab. ${ }^{5}$

Abad Renaisans ditandai dengan munculnya sejumlah ilmuwan dan filsuf yang menentang doktrin gereja terutama tentang ilmu bumi. Mereka menganggap bahwa pusat dunia bukan lagi Tuhan, melainkan manusia. Manusialah yang berhak dan harus menentukan masa depannya sendiri dan tidak menyerah pada takdir. Sebagai makhluk yang berakal, seyogyanya manusia harus mampu menaklukkan dunia beserta isinya. Berikut adalah sejumlah penemu Eropa dan gerakan-gerakan yang terkait dengan proses Renaisans yang di kemudian hari mengantarkan orang-orang Eropa untuk menjelajahi dunia dan membuka kolonikoloni dagang di penjuru benua Asia, Afrika, dan Amerika. ${ }^{6}$

Awal mula dari suatu masa baru ditandai oleh suatu usaha besar Descartes (1596 -1650) untuk memberikan kepada filasafat suatu bangunan yang baru. Memang di dalam bidang filsafat zaman Renaisans kurang menghasilkan karya penting bila dibandingkan dengan bidang seni dan sains. Namun di antara perkembangan itu terjadi pula perkembangan dalam filsafat. Descartes sering disebut sebagai tokoh pertama filsafat modern. ${ }^{7}$

Sejak itu, dan juga telah dimulai sebelumnya, yaitu sejak permulaan Renaisans, sebenarnya Individualisme dan Humanisme telah dicanangkan. Descartes memperkuat idea-idea ini. Humanisme dan individualisme merupakan ciri Renaisans yang penting. Humanisme ialah pandangan bahwa manusia

${ }^{3}$ Simon Pitrus L. Tjahjadi, Petualangan Intelektual, Konfrontasi dengan Para Filsuf dari Zaman Yunani hingga Zaman Modern (Jakarta: Pustaka Filsafat), h 176

4Burns, Edward Marshl and Philip Lee Ralph, Word Civilization From Ancient to Contemporery (New York: W.W. Norton and Company, 1964), h 516.

${ }^{5}$ Berkhof, I.H. Enklaar, Sejarah Gereja (Jakarta: BPK Gunung Mulia, 1986), h 256.

6Theo Huijbers, Filsafat Hukum Dalam Lintasan Sejarah (Jakarta: Kanisius), 1996, h 50.

${ }^{7}$ Harun Hadiwijono, Sari Sejarah Filsafat Barat 2 ( Jakarta: Kanisius), h 18. 
mampu mengatur dunia dan dirinya. Oleh karena itu sering juga disebut zaman Humanisme, maksudnya manusia diangkat dari abad pertengahan. ${ }^{8}$

Pada abad pertengahan itu manusia dianggap kurang dihargai sebagai manusia. Kebenaran diukur berdasarkan ukuran dari Gereja (Kristen), bukan menurut ukuran yang dibuat oleh manusia. Humanisme menghendaki ukuran haruslah manusia. Karena manusia mempunyai kemampuan berpikir, maka Humanisme menganggap manusia mampu mengatur dirinya sendiri dan mengatur dunia.

\section{B. Transmisi Ilmu pengetahuan Islam ke Eropa}

Dunia Islam pernah mencapai masa keemasan di bidang sains, teknologi, dan filsafat tepatnya di bawah Dinasti Abbasiyah yang berkuasa sekitar abad-8 sampai abad 15. Lebih lanjutnya bahwa sarjana muslin menjadi jembatan dan perantara bagi kemajuan ilmu pengetahuan di dunia modern saat ini. Dari dunia Islam, Ilmu pengetahuan mengalami transmisi, diseminasi, dan proliferasi ke dunia Barat yang mendukung muculnya zaman Renaisans di Eropa. Melalui dunia Islam, barat mendapat akses untuk mendalami dan mengambangkan ilmu pengetahuan modern. ${ }^{9}$

Manusia modern lebih banyak berhutang dari pada yang disangkanya kepada sarjana-sarjana Islam abad pertengahan. Mereka menjadi ahli kimia, dokter, ahli ilmu bintang, ahli matematika, ahli ilmu bumi, ahli muslim lainnya, bukan hanya menghidupkan disiplin-disiplin ilmu pengetahuan Yunani, melainkan memperluas jangkauannya, meletakkan dan memperkuat dasar-dasar, tempat tumpuan bagi terbitnya ilmu pengetahuan modern. ${ }^{10}$

Sains adalah sumbangan terbesar peradaban Islam kepada dunia modern, tetapi buahnya lambat masaknya. Tidak lama setelah kebudayaan Moor (Arab Spanyol) terbenam kedalam kegelapan, maka raksasa yang dilahirkannya bangkit dalam keperkasaannya. Bukan hanya sains yang telah menghidupkan kembali Eropa, melainkan pengaruh peradaban Islam yang lainnya juga menghidupkan Eropa. ${ }^{11}$

Dalam sejarah terdapat tempat-tempat dan proses yang mempengaruhi pemikiran dan sains Barat oleh pemikiran dan sains Islam yaitu: Andalusia, Shaqalliyah (Sisilia), Perang Salib di Syria dan Sekitarnya, Qustanthiniyah (Konstantinopel):

8Thomas Hidya Djaya, Humanisme dan Skolatisme: Sebuah Debat ( Jakarta: Kanisius), h 34.

${ }^{9}$ Agus Purwanto, Ayat Ayat Semesta: Sisi-Sisi Al-Qur'an yang Terlupakan (Bandung: PT Mizan Publika), h 23.

${ }^{10}$ Haidar Baqir, "Jejak-jejak sains Islam Dalam Sains Modern", Dalam Jurnal Qur'an (Jakarta: edisi Juli-September 1989), h 34.

${ }^{11}$ Ibid., h 35 


\section{Andalusia (Spanyol)}

Masuknya Islam ke Spanyol yaitu setelah Abdur Rahman ad-Dakhil (756M) berhasil membangun pemerintahan yang berpusat di Andalusia dan pertengahan abad ke-9 M Islam telah meliputi seluruh Spanyol. Phillip K. Hitti mengungkapkan bahwa kaum Muslimin Spanyol telah menorehkan catatan yang paling mengagumkan dalam sejarah intelektual pada abad pertengahan di Eropa. Antara abad 2-7H/8-13M, cendikiawan dan ulama Islam telah membawa perkembangan kebudayaan dan peradaban penting ke seluruh pelosok dunia. Di samping itu mereka juga merupakan peranan yang menghubungkan ilmu dan filsafat Yunani klasik sehingga khazanah kuno itu ditemukan kembali. Tidak hanya sebagai mediator, tetapi mereka juga memberikan beberapa penambahan dan proses transmisi sedemikian rupa sehingga memungkinkan lahirnya pencerahan di Eropa Barat. Dalam semua proses tersebut bangsa Arab-Spanyol mempunyai andil yang sangat besar. ${ }^{12}$

Para pencari ilmu dari Eropa Barat telah berduyun-duyun mendatangi mendatangi Andalusia untuk menimba ilmu. Kejayaan ini mencapai puncaknya pada abad ke-11 M. ketika para ulama dan pakar muslim berdatangan ke Andalusia dari Iraq, Syam dan Mesir, karena pemerintah Muslim Andalusia benar-benar memberi tempat terhormat bagai para ilmuwan. Mereka memboyong literatur-literatur dari Timur dalam berbagai ilmu ke Andalusia. Dinamika keilmuan dan peradaban ini terus berlanjut sekalipun kekuasaan muslim Spanyol tercabik-cabik. ${ }^{13}$ Oleh karena itu tidaklah mengherankan jika pada saat kekhilafahan Islam berkuasa saat itu Spanyol menjadi pusat pembelajaran (centre of learning) bagi masyarakat Eropa dengan adanya Universitas Cordova.

Universitas di Andalusia (Spanyol) biasa menjadi ajang pertemuan para akademis dan ruang pembacaan publik tempat untuk membacakan puisi-pusi asli atau menyampaikan pidato. Salah satu slogan favourite yang tertera di atas portal masuk Universitas berbunyi “Dunia hanya terdiri atas empat unsur: pengetahuan yang bijak, keadilan penguasa, doa orang soleh dan keberanian ksatria."14

Di Universitas Andalusia ini banyak kaum intelektual menimba ilmu, dan dari negeri tersebut muncul nama-nama 'ulama besar seperti Imam al-Syathibi pengarang kitab Al-Muwafaqat, sebuah kitab tentang Ushul Fiqh yang sangat berpengaruh; Ibnu Hazm Al-Andalusi pengarang kitab Al-Fashl fi al-Milal wa alAhwa' wa an-Nihal, sebuah kitab tentang perbandingan sekte dan agama-agama dunia, dimana bukti tersebut telah mengilhami penulis-penulis Barat untuk melakukan hal yang sama.

Semaraknya pengembangan ilmu pengetahuan Islam di Spanyol juga diikuti dengan banyaknya perpustakaan tersebar di Spanyol yang jumlah

12Phillip K. Hitti, History of the Arabs (New York : Palgrave Macmillan 2002), h 737

${ }^{13}$ Abdul Aziz al-Khuwaithir dkk. Al-'Alam al-Islami (Wizarah al-Ma'arif-KSA, 1395/1975), h 146.

14Ibid., h 717 
bukunya sangat fantastis. Sejarah mencatat, perpustakaan di Cordova pada abad 10 Masehi mempunyai 600.000 jilid buku. Perpustakaan Al Hakim di Andalusia mempunyai berbagai buku dalam 40 kamar yang setiap kamarnya berisi 18.000 jilid buku. Sementara ratusan tahun sesudahnya (abad $15 \mathrm{M}$ ), menurut catatan Catholik Encyclopedia, perpustakaan Gereja Canterbury yang merupakan perpustakaan dunia Barat yang paling kaya saat jumlah bukunya tidak melebihi 1.800 jilid buku. ${ }^{15}$

Andalusia saat itu menjadi pusat pengembangan ilmu pengetahuan, tempat cendikiawan dan ulama Islam di Barat dan Cordova serta menjadi kota raksasa Islam yang menerangi dunia dengan cahaya gilang-gemilang sehingga universitasnya pada saat itu juga dipenuhi oleh banyak mahasiswa Katolik dari Perancis, Inggris, Jerman dan Italia. Pada masa itu, para pemuda Kristen dari berbagai negara di Eropa dikirim berbondong-bondong ke sejumlah perguruan tinggi di Andalusia guna menimba ilmu pengetahuan dan teknologi dari para ilmuwan muslim. Gerard dari Cremona; Campanus dari Navarra; Aberald dari Bath; Albert dan Daniel dari Morley yang telah menimba ilmu demikian banyak dari para ilmuwan muslim, untuk kemudian pulang dan menggunakannya secara efektif bagi penelitian dan pengembangan di masing-masing bangsanya. Dari sini kemudian sebuah revolusi pemikiran dan kebudayaan telah pecah dan menyebarluas ke seluruh masyarakat dan seluruh benua. Para pemuda Kristen yang sebelumnya telah banyak belajar dari para ilmuwan muslim, telah berhasil melakukan sebuah transformasi nilai-nilai yang unggul dari peradaban Islam yang kemudian diimplementasikan pada peradaban mereka (Barat) yang selanjutnya berimplikasi terhadap kemajuan diberbagai bidang ilmu pengetahuan.

Apalagi setelah Toledo jatuh ke tangan Kristen pada tahun 478 H/1085M,16 menjadikan kota itu sebagai pusat saluran utama proses peralihan khazanah ilmu pengetahuan Islam yang berbahasa Arab ke Eropa. Di Toledo Uskup Bear Raymond I (520-547H/1126-1152M) membangun sekolah khusus penterjemah dan sekolah kajian orientalisme yang pertama di Eropa, atas permintaan para pendeta dengan tujuan utama untuk mempersiapkan para misionaris Kristen ke kalangan Islam. Penterjemah dari Toledo yang paling produktif adalah Gerard Cremona, telah menterjemahkan ke dalam bahasa Latin karya berbahasa Arab sebanyak 71 judul. ${ }^{17}$ Pada akhir abad 7H/13M ilmu pengetahuan dan filsafat Arab telah dipindahkan ke Eropa yang bergerak dari Todelo melalui Pyrenees, Provence dan Alpine terus ke kawasan Lorraine, Jerman, Eropa Tengah dan daratan Inggris Raya.

${ }^{15}$ M. Sahari Besari, Teknologi Nusantara: 40 Abad Hambatan Inovasi (Jakarta: Salemba, 2008), h 58.

${ }^{16}$ Lembaga Studi Agama Dan Filsafat, Ulumul Qur'an (Jakarta: 1992) Vol 3, h 32.

${ }^{17}$ Lisga Hidayat Siregar, Sejarah Peradaban Islam Klasik (Bandung : Citapustaka Media perintis, 2010), h 202. 
Sebagai pusat peradaban Islam Andalusia telah memberikan kontribusi yang besar terhadap tumbuh dan berkembangnya peradaban modern di dunia Eropa.

\section{Shaqoliyah (Sisilia) الصثلية}

Berakhirnya kekuasaan Islam di Sisilia ditandai dengan runtuhnya kerajaan kalbiyah, setelah hampir dua abad Islam menguasai Sisilia. Pangeran Roger I putra Tancred de Hauteville dari Normandia merebut kota Messina tahun 452H/1060M, menyusul kota Palermo tahun 464H/1071M, Siracuse tahun $478 \mathrm{H} / 1085$, dan dipungkas dengan penaklukan Maltra tahun 483H/1090 M.

Roger I (w.495H/1101M) yang menguasai Sisilia, tetap melindungi para cendikiawan, filosof dan astrolog Arab dan para dokter, dan memberi kebebasan penuh kepada masyarakat non kristen untuk menjalankan ibadah sesuai dengan ajaran agamanya. Istana Palermo lebih bernuansa ketimuran (Arab) ketimbang barat. Lebih dari satu abad setelah Sisilia dikuasai Kristen, beberapa jabatan penting masih dipegang oleh umat Islam. Pengaruh Arab di Sisilia dimulai oleh Roger I, dan mencapai puncaknya pada masa anaknya Roger II (525-549H/11301154M) dan Frederik II. Roger II berpakaian layaknya muslim, jubahnya dihiasi karakter-karakter Arab, bahkan ketika cucunya William II (562-585H/1166$1189 \mathrm{M})$ berkuasa, beberapa wanita Kristen di Palermo Ibukota Sisilia mengenakan pakaian Muslim. ${ }^{18}$

Adalah Fredrik II (612-684H/1215-1250M) yang merupakan cucu Roger II dan penguasa sipil tertinggi di dunia kristen serta penguasa Sisilia dan Jerman juga pemegang jabatan kaisar suci Romawi dan raja Jerussalem karena hubungan perkawinannya dengan pewaris kerajaan yaitu Isabelle.

Musyrifah Sunanto dalam bukunya Sejarah Islam Klasik Perkembangan Ilmu pengetahuan Islam yang kemudian dibahasakan ulang oleh Lisga Hidayat Siregar menuturkan bahwa Frederik II mempunyai seorang penterjemah Theodore (Thadhuri), yang menterjemahkan karya-karya berbahasa Arab ke dalam bahasa Latin seperti Sirr al-Asrar tentang ilmu kesehatan Theodore telah menghadirkan gambaran tentang muslim Spanyol terpelajar di Sisilia dan Italia. Universitas Naples, didirikan Frederik II pada tahun 621H/1224M, merupakan Universitas pertama di Eropa. Universitas ini menyediakan koleksi naskah-naskah berbahasa Arab yang sangat berlimpah. Karya Aristoteles dan Ibn Rusyd, diperintahkan Frederik untuk diterjemahkan dan digunakan dalam kurikulum. Salinan terjemahan ini dikirim ke Universitas-universitas di Eropa seperti Bologna dan Paris. Salah seorang alumni universitas Naples ialah Thomas Aquinas, pemimpin Katolik yang terkenal. ${ }^{19}$

Pada abad 8H/14M dan abad-abad berikutnya, kajian berbahasa Arab dipelajari di universitas-universitas di Eropa, seperti di Oxford dan Paris tetapi

${ }^{18} \mathrm{Hitti}$, History of the Arabs, h 775.

${ }^{19}$ Lisga, Sejarah Peradaban Islam Klasik, h 778. 
dengan tujuan untuk menyiapkan para misionaris Kristen untuk dikirim ke wilayah-wilayah Muslim. ${ }^{20}$ Ensiklopedia kedokteran karya al-Razi satu-satunya karya besar dalam bidang kedokteran yang diterjemahkan oleh Faraj ben Salim seorang dokter Yahudi Sisilia ke dalam bahasa Latin pada tahun 678H/1279M telah diterbitkan dalam berbagai manuskrip pada abad-abad berikutnya. Pada saat itu banyak diterjemahkan buku dalam bidang astronomi dan matematika. Palermo ibukota Sisilia menjadi tempat kegiatan penterjemahan buku-buku ulama yang diterjemahkan ke dalam bahasa Latin. Kemudian dibawa ke Eropa bagian Selatan, yang kemudian melahirkan Renaisance Italia. ${ }^{21}$ Uraian ini jelas mengungkapkan bahwa Sisilia mempunyai kontribusi dan peran yang signifikan dalam proses pewarisan khazanah ilmiah ke Eropa.

\section{Perang Salib}

Syria dan sekitarnya, seperti diketahui, adalah wilayah di mana Islam dan Barat berjumpa dalam bentuk perang Salib. Perang yang berlangsung antara 1095 sampai 1291 ini, $^{22}$ sedikitnya punya pengaruh terhadap transmisi pemikiran dan sains Islam ke Barat. Kendati demikian, disadari bila pengaruh perang salib di sini tidaklah begitu intens, mengingat orang-orang yang datang sebagai pasukan Salib adalah ksatria-ksatria perang dan bukan ilmuan. Sehingga, dapat dikatakan bahwa sekiranya pun terjadi transmisi akibat perang salib tetapi bentuknya tak lebih dari peniruan tatacara hidup sebagai hasil kekaguman Barat-dalam hal ini pasukan Salib - terhadap masyarakat Islam yang mereka lihat. Transmisi terlihat terutama pada kemiliteran, arsitektur, teknologi pertanian, industri, rumah-rumah sakit, permandian umum, dan dalam batas tertentu juga sastra.

Di samping dua bentuk yang mengakibatkan terjadinya transmisi pemikiran dan sains Islam ke Barat, tak sedikit historian melihat bila terdapat pula pengaruh kontak pribadi dalam proses itu. Pandangan ini berangkat dari satu kenyataan bahwa sejak penaklukan Syria, Mesir dan Persia oleh ekspedisiekspedisi Islam sejak khalifah 'Umar ibn al-Khattab, tak sedikit orang-orang Kristen di Timur (Bizantium) menjalin kontak pribadi dengan orang-orang Islam. Karena semangat liberasi, moderasi dan toleransi yang dimiliki umat Islam, sehingga orang-orang Kristen tidak menemukan halangan dalam mengikuti kegiatan intelektual dan kebudayaan kaum Muslim. Tak jarang di antara mereka menjadi tokoh-tokoh penting dalam gerakan keilmuan Islam yang lahir kemudian. Mereka pula yang kelak banyak membantu menerjemahkan karyakarya keilmuan Yunani ke dalam bahasa Arab, dan selanjtnya, terutama pada paruh awal abad ke-11, karya-karya terjemahan berbahasa Arab itulah yang diterjemahkan ke dalam bahasa Latin oleh sarjana-sarjana Barat.

\footnotetext{
${ }^{20}$ Hitti, History of the Arabs, h 780.

${ }^{21}$ Harun Nasution, Ensiklopedia Islam Indonesia (Jakarta: Penerbit Djambatan, 2002), Jilid II, h 302 .

22Dewi Cendika, Shalahuddin al-Ayyubi (Bandung: PT Mizan Publika, 2009), h 16.
} 


\section{Konstantinopel}

Pada masa pemerintahan Muhammad II (pertengahan abad ke-15 M). kerajaan Turki Usmani telah mencapai puncak kejayaannya. Sehingga pada tanggal 29 Mei 1453, Muhammad al-Fatih berhasil menaklukkan benteng Konstantinopel yang terkuat, lambang Imperium Bizantium. Dengan demikian para Khilafah Utsmani mengakhiri abad kegelapan di Eropa dan memberikan cahaya baru.

Suatu yang unik, ketika Konstantin II meminta bantuan kepada Paus untuk menyatukan gereja ortodoknya dengan gereja Katolik Roma demi menghadapi Turki Utsmani, penduduk Konstantinopel menentang persatuan itu bahkan mereka lebih memilih melihat surban-surban orang muslim berada di jantung ibu kota mereka dari pada melihat peci tokoh katolik di sana.23

Dengan dipindahkannya Ibukota Khilafah Utsmaniyah ke Konstantinopel, maka berahirlah kekuasaan Bizantium dan Konstantinopel memasuki babak baru yang penuh dengan ilmu, kemakmuran dan kemajuan.

Di Konstantinopel ini terjadi kontak antara muslim dan kristen ortodok. Tindakan Turki Utsmani yang toleran terhadap non muslim makin membantu terjadinya proses transpormasi nilai-nilai Islam ke Barat. Disini tidak terlalu banyak pengaruh sains Islam terhadap Barat. Sebab barat ketika itu sedang serius mempelajari dan mengembangkan sains Islam yang sudah diboyong dua abad sebelumnya, bahkan pada akhirnya Barat melampaui Turki Utsmani.

\section{Transmisi Pemikiran Dan Sains Islam Ke Eropa}

Transmisi pemikiran dan sains Islam ke Barat pada awal abad pertengahan melewati beberapa tahap. ${ }^{24}$ Pertama, sekolompok sarjana Barat mengunjungi wilayah-wilayah muslim untuk melakukan kajian-kajian pribadi. Constantinus Africanus dan Adelhard adalah perintis-perintisnya. Kemudian disusul oleh para pelopor dari Itali, Spanyol dan Perancis. Mereka menghadiri seminari-seminari muslim untuk belajar matematika, filsafat, kedokteran, kosmografi, dan lain-lain. Dalam waktu singkat mereka menjadi calon-calon Profesor di UniversitasUniversitas pertama di Barat, yang dibangun dengan menyontoh dari seminariseminari muslim tersebut.

Kedua, bermula dengan pendirian Universitas-Universitas pertama Barat. Gaya arsitektur, kurikulum, dan metode pengajarannya persis sama dengan yang ada di seminari-seminari muslim. Pertama seminari Palermo didirikan di kerajaan Napoli (Naples). Oleh Raja Frederick II, kemudian Universitas-Universitas penting berdiri di Padua, Toulause, baru di Leon.

Ketiga, pada tahab ini sains Islam berhasil ditransmisikan ke Perancil dan wilayah-wilayah Barat lewat Itali. Seminari-seminari di Bologna dan Mont Rellier didirikan pada awal abad ke-13, kemudian Universitas Paris di buka (1213 M).

\footnotetext{
${ }^{23}$ Abdul Aziz, Al-'Alam al-Islami, h 213-214.

${ }^{24}$ Haedar Baqir, "Jejak-jejak sains Islam Dalam Sains Modern”, h 55
} 
sementara itu, sains Islam sampai ke Inggris dan Jerman lewat UniversitasUniversitas Oxford dan Kala, yang didirikan dengan pola yang sama.

Berkenaan dengan pendirian Universitas-Universitas ini, Herbert A. Davies mengatakan: "Mereka (orang-orang Muslim) mendirikan Universitas-Universitas besar selama berabad-abad melebihi yang dipunyai oleh Eropa Kristen. Universitas Bagdad, Kairo, Kordoba, khususnya yang termasyhur Universitas Kairo (kini sudah berumur lebih dari sepuluh abad) memiliki mahasiswa sebanyak 12 ribu orang. Perpustakaan-perpustakaan besar dibangun, beberapa diantaranya berisi beratus-ratus ribu jilid buku yang semuanya terdaftar dan tersusun rapi. Banyak orang Kristen yang belajar di Universitas Kordoba, (kemudian) membawa ilmu dan kebudayaan ke negeri-negeri mereka, pengaruh universitas Spanyol (Islam) atas Universitas Paris, Oxford dan UniversitasUniversitas yang mereka bangun di Itali tentunya sangat besar" ${ }^{\prime 2}$

Pengaruh pemikiran dan sains Islam yang berlangsung sejak abad ke-12 M akhirnya menimbulkan gerakan Kebangkitan Kembali (Renaisans) pada abad ke 14 M, gerakan Reformasi gereja pada abad ke-16 M, gerakan Rasionalisme pada abad ke-17 M, revolusi industri serta pencerahan (aufklaerung) pada abad ke-18 M. ${ }^{26}$ Berikut adalah percikan dari cahaya Islam yang banyak ditutup-tutupi yaitu:

\section{Pertanian.}

Bangsa Arab sangat mahir dibidang pertanian, mereka bertani berdasarkan ilmu, mereka dengan serius memasukkan bermacam-macam tumbuhan ke Spanyol seperti tebu, pohon tut (buahnya di makan dan daunnya untuk ulat sutra), padi, kapas, buah-buahan dan lain-lain. Mereka pandai bercocok tanam dan irigasi. Penelitian-penelitian ilmiah mereka tentang pertanian, perkebunan dasn pertanahan di bukukan. Mereka pemerhati unggulan dalam penelitian tersebut adalah Ibn al-Awam al-Isybili 586 H (1190 M). dalam karyanya Kitab al-Falahah. Dia menguraikan berbagai macam tanah, bermacam-macam pupuk, dia menerangkan cara membudidayakan 585 macam tumbuhan dan 50 macam buah. Lebih dari itu dia menjelaskan cara merawat, gejala-gejala penyakit dan cara membasmi hama tanaman. Jadi ilmu pertanian telah rampung kodifikasinya pada abad pertengahan abad keemasan Islam. ${ }^{27}$

Warisan Islam yang satu ini tidak dipungkiri oleh orang-orang Spanyol karena ada seribu dalil yang bisa membuktikannya. Sampai sekarangpun mereka masih mengenang pernyataan seorang Arab (Islam) "segala sesuatu di Dunia ini terdapat di Sevilla hingga susu burung pipit".28

\footnotetext{
${ }^{25} \mathrm{Ibid}$

${ }^{26}$ Badri Yatim, Sejarah Peradan Islam (Jakarta: Raja Grafindo 2000), hlm. 110

${ }^{27}$ Abdul Aziz, Al-'Alam al-Islami, h 149.

${ }^{28}$ Anonim, Isybiliyah Humsh al-Gharb wa Tuhfah al-Majd, Majalah al-Wa'y al-Islami (Kuwait:
} Edisi 252, Dzulqaidah 1405), h 84. 


\section{Industri}

Sebagian hasil industri telah dimasukkan oleh kaum Muslim ke Spanyol, diantaranya adalah produksi Kertas. Pabrik kertas pertama di Eropa adalah di Asbania pada pertengahan abad ke-12 M. dan pusat industri pertama adalah di Balansia, Syathiba dan Toledo. ${ }^{29}$ Berbagai macam peralatan dari tambang seperti pisau, pedang ada di sana, hiasan-hiasan dan ukiran dari tambang juga ada. ${ }^{30}$ Industri yang paling penting adalah inovasi senjata api yang disebut "Barud" (pistol) adalah murni penemuan orang Arab Muslim. ${ }^{31}$

\section{Metode Keilmuan}

Barat menganggap bahwa Roger Bacan adalah penemu metode keilmuan, ini adalah pengingkaran sejarah, Briffault menyatakan bahwa Roger tak lebih dari utusan sains dan metode muslim pada Eropa Kristen. Dia belajar Bahasa Arab di Perancis pada tahun 1240-1250 dan 1257-1268, dengan modal bahasa Arab ia belajar ilmu pasti dan keIslaman lalu menerjemah dari bahasa Arab apa yang belum diterjemah dan Opus Majusnya adalah hasil plagiat dari Al-Syifa karya Ibn Sina. ${ }^{32}$ Kemudian datang Francis Bacon (1561-1627) menyebarkan teori induksi dan deduksi dan metode eksperimen lewat karya-karyanya yang dianggap standar.

\section{Angka Arab dab Matematika}

Muahmmad Ibn Musa al-Khawarizmi (780-850 M) adalah perintis aljabar, bukunya "Al-Jabr wa Al-Muqabalah" adalah buku yang menyebarkan penggunaan angkaangka arab dan sistem persepuluhan. Tanpa itu semua matematika dan aritmatika modrn tidak terbayangkan. Beberapa rumus ilmu ukur, termasuk mengenai segi tiga, daftar logaritma dan sistem persepuluhan adalah penemuannya, bukan penemuan John Naiper (1550-1617) atau Simon Stevin (1548-1620). ${ }^{33}$

\section{Kedokteran}

Cukuplah dijadikan sebagai satu contoh Ibn. Sina (980-1307 M) dengan karyanya al-Qanun fi at-Thibb yang menjadi referensi utama sampai abad ke-19. Terutama tentang penyakit syaraf. Dapat dikatakan bahwa antara abad ke-13 sampai abad ke-16 tidak ada ahli kedokteran Barat yang bisa melepaskan diri dari pengaruh Ibn Sina. ${ }^{34}$

Tokoh lain adalah Ibn Nafis $(687 \mathrm{H})$ adalah penemu pertama aliran darah, sedang Az-Zahrawi Abu Al-Qasim Khalaf (404 H/1013) adalah dokter ahli bedah yang sangat tyerkenal dan bukunya menjadi rujukan berabad-abad lamanya.

\footnotetext{
${ }^{29}$ Abdul Aziz, Al-'Alam al-Islami, h 149.

${ }^{30}$ ibid, h 157.

${ }^{31}$ Ibid, h 149 .

${ }^{32}$ Haidar Baqir, "Jejak-jejak sains Islam Dalam Sains Modern", h 57.

${ }^{33}$ Ibid., h 58.

${ }^{34}$ Ibid
} 
Apa yang telah dijelaskan diatas merupakan beberapa contoh dari ratusan saintis muslim disegala bidang yang berkembang pesat pada abad pertengahan dimana Eropa (Barat) sedang kelam dan gulita. Hal ini perlu dikuak kembali dalam rangka mencari ruh dari perkembangan ilmu pengetahuan di era global ini sehingga generasi Muslim tidak silau dan buta dibuatnya, akan tetapi bagaimana mengembalikan kejayaan itu dengan nafas-nafas keIslaman sebagaimana para ulama dulu khususnya yang hidup di abad pertengahan ini.

\section{Astronomi dan Ilmu Pasti}

Dalam bidang ini sarjana Islam al-Khawarizmi banyak sekali menyumbang dengan karya karyanya dan mempunyai pengaruh terbesar atas pelik pelik ilmu pasti di abad pertengahan. Ia menulis buku Al jabr wa al-Muqabalah, suatu buku standar ilmu pasti. Buku tersebut memuat daftar astronomi yang tertua dan alKhawarizmi merupakan orang pertama yang menyusun buku ilmu berhitung dan aljabar. Kitab inilah yang memperkenalkan ilmu aljabar serta nama itu sendiri di benua Eropa. Pengaruhnya diperkuat dengan kenyataan bahwa 'alogarisme' untuk waktu yang lama berarti 'aritmatik' dan dewasa ini dipergunakan sebagai metode untuk mengkalkulasi yang kini telah dibakukan. Begiu pula bapak kimia Islam, Jabir Ibnu Hayyan, (721-815M). Kitab kimianya merupakan buku yang paling berpengaruh di Eropa dan Asia sampai sesudah abad 14.

\section{Filsafat}

Sumbangan Islam pada dunia barat dalam hal filsafat adalah Ibnu Rusyd (11261198M), dan Al Kindi (809-873M). Ibnu Rusyd dikenal sebagai komentator fikiran fikiran Aristoteles, karenanya dijuluki Aristoteles II, pengaruhnya sangat menonjol atas pendukung filsafat skholastik Kristen dan fikiran fikiran sarjana Eropa pada Abad pertengahan. Sedang Al Kindi terkenal dengan metode filsafatnya yang menggabungkan dalil dalil Plato dan Aristoteles dengan cara Neo-Platonis.

\section{Ilmu Sejarah dan Sosiologi}

Dalam ilmu sejarah dan sosiologi, muncul nama Ibnu Khaldun (1332-1406M) dengan karya Muqaddimah-nya yang telah memberikan sumbangan dan pengaruh terhadap pemikiran pemikiran sarjana barat. Dialah yang pertama kali mengemukakan teori perkembangan sejarah, baik berdasarkan penyelidikan faktor faktor jasmani dan iklim, mapun kekuatan moral dan rohani.

\section{PENUTUP}

Renaisans, berasal dari kata Re, (kembali) dan Neitre (lahir) berarti 'kelahiran kembali.' Dalam konteks sejarat barat, istilah ini mengacu pada terjadinya kebangkitan kembali minat yang sangat besar dan mendalam terhadap kekeyaan warisan Yunani dan Romawi kuno dalam berbagai aspeknya. 
Sarjana muslin menjadi jembatan dan perantara bagi kemajuan ilmu pengetahuan di dunia modern saat ini.dari dunia Islamlah, ilmu pengetahuan mengalami transmisi, diseminasi, dan proliferasi ke dunia Barat yang mendukung muculnya zaman Pencerahan (Renaisans) di Eropa. Melalui dunia Islam, barat mendapat akses untuk mendalami dan mengambangkan ilmu pengetahuan modern. Dalam sejarah terdapat tempat-tempat dan proses yang mempengaruhi pemikiran dan sains Barat oleh pemikiran dan sains Islam yaitu: Andalusia, Shaqalliyah (Sisilia), Perang Salib di Syria dan Sekitarnya, Qustanthiniyah (Konstantinopel).

Bentuk Kontribusi ilmu pengetahuan Islam terhadap Bangsa Barat antara lain. Diantaranya: Kedokteran, Pertanian, Astronomi, Sosiologi, Matematika, Sejarah dan banyak juga yang mempelajari metode keilmuan dari orang-orang Islam di masa pertengahan.

\section{REFERENSI}

Anonim. Isybiliyah Humsh al-Gharb wa Tuhfah al-Majd. Kuwait: Edisi 252. Dzulqaidah. 1405H.

Baqir, Haidar. "Jejak-jejak sains Islam Dalam Sains Moder", Dalam Jurnal Qur'an. Jakarta: edisi Juli-September. 1989.

Besari, M. Sahari. Teknologi Nusantara: 40 Abad Hambatan Inovasi. Jakarta: Salemba. 2008

Cendika, Dewi. Shalahuddin al-Ayyubi. Bandung: PT Mizan Publika. 2009

Djaya, Thomas Hidya. Humanisme dan Skolatisme: Sebuah Debat. Jakarta: Kanisius.

Enklaar, Berkhof, I.H. Sejarah Gereja. Jakarta: BPK Gunung Mulia. 1986.

Hadiwijono, Harun. Sari Sejarah Filsafat Barat 2. Jakarta: Kanisius.

Hitti, Phillip K. History of the Arabs, New York : Palgrave Macmillan. 2002.

Huijbers, Theo. Filsafat Hukum Dalam Lintasan Sejarah. Jakarta: Kanisius. 1996.

al-Khuwaithir Abdul Aziz, dkk.. Al-'Alam al-Islami. Wizarah al-Ma'arif-KSA, 1395/1975.

Lembaga Studi Agama Dan Filsafat. Ulumul Qur'an Vol 3. Jakarta: 1992.

Nasution, Harun. Ensiklopedia Islam Indonesia. Jakarta: Penerbit Djambatan. Jilid II. 2002.

Ralph, Burns, Edward Marshall and Philip Lee. Word Civilization From Ancient to Contemporery. New York: W.W. Norton and Company. 1964.

Siregar, Lisga Hidayat. Sejarah Peradaban Islam Klasik. Bandung : Citapustaka Media perintis. 2010. 
Suhelmi, Ahmad. Pemikiran Politik Barat. Jakarta: Gramedia Pustaka Utama. 2007.

Tjahjadi, Simon Pitrus L. Petualangan Intelektual, Konfrontasi dengan Para Filsuf dari Zaman Yunani hingga Zaman Modern. Jakarta: Pustaka Filsafat.

Yatim, Badri. Sejarah Peradan Islam. Jakarta: Raja Grafindo. 2000. 